\title{
Crise: divisão. Crise de visão?
}

Em 2008, descobriu-se que o vigor econômico exibido na última década pelos norte-americanos era desproporcional à realidade. E, no pior momento da atual crise econômica mundial, Warren Buffet - o investidor americano que, quando está pobre, é o segundo homem mais rico do mundo - arregaçou as mangas e foi às compras. Exatamente enquanto muitos se desfaziam de seus ativos, ele comprava. $\mathrm{Na}$ verdade, não só ele. Para cada pessimista que vende uma ação, há um otimista que a compra. Em outra perspectiva, somos divididos em dois grupos: pessimistas e otimistas.

Os pessimistas são os que travam na crise. As dificuldades que se acenam são respondidas apenas com negativismos e cortes. Tanto nas análises quanto nos planejamentos e investimentos. Eles, em uma noite de pesadelo, prendem o fôlego, escondem-se debaixo da coberta e esperam o dia raiar.

Os otimistas levantam-se da cama, acendem a luz e focam seu pensamento em uma noite melhor. É deles que saem as soluções criativas para as dificuldades. Em mandarim, o símbolo para crise é composto de duas subunidades: uma significa perigo, a outra oportunidade. São os otimistas que enxergam as oportunidades e procuram se posicionar e brilhar nessas horas. Muhtar Kent, presidente mundial da Coca-Cola, disse: "uma coisa que não fazemos na crise é cortar marketing. Queremos sair desse túnel escuro com mais participação de mercado do que entramos". Para um produto que não requer inovação, o marketing é o que mais importa.

Nossos serviços, diferentemente dos produtos da Coca-Cola, são inovadores e mutáveis. Consequentemente, nossa energia não pode ser tão concentrada em marketing. Analistas de mercado e headhunters concordam que é nos momentos de crise que precisamos investir em formação e conhecimento. Essa fórmula garante a luz necessária para transitar no túnel da crise e sair dele com uma estrutura melhor.

$\mathrm{Na}$ Odontologia brasileira, a crise mundial provocou impactos tão diversos quanto a extensão de nosso território. Algumas regiões foram mais afetadas do que outras. Todavia, no geral, a crise mundial não entrou em nossas fronteiras como o fez em outros países. Isso foi fruto de análises, planejamentos e investimentos feitos, no passado recente, na área econômica. Ao mesmo tempo, a crise esbarra numa época curiosa para a Odontologia brasileira.

A despeito dos problemas externos, e mesmo dos internos, o Brasil possui muitos dos melhores cirurgiões-dentistas do mundo, tanto nos aspectos clínicos como científicos. Não precisamos viajar para outros países para completar nossa formação. Não precisamos olhar com admiração aspirante para nenhum outro lugar.

Assim, minhas colocações querem levar ao óbvio: a crise vai passar, o túnel vai acabar. Entretanto, não há fôlego que resista ao seu comprimento. Aqueles que enxergarem as oportunidades lucrarão, pessoal e profissionalmente, em breve.

Como só se enxerga com luz, precisamos estar acesos ao conhecimento. Isso significa comparecer a seminários e congressos, bem como manter uma leitura sintonizada com os rumos de nossa especialidade.

Nesse número da revista, podemos checar alguns assuntos que estão claramente em acordo com o exposto, tal como o trabalho de Santiago et al. sobre a densidade mineral óssea de sítios específicos da maxila para a inserção de mini-implantes, ou mesmo o de Silva et al. sobre a percepção dos auxiliares odontológicos na clínica ortodôntica quanto aos seus limites de atuação profissional. Esse último trabalho é especialmente relevante, em decorrência da recente sanção da lei que regula a atuação profissional dessa categoria.

Muito otimismo,

Jorge Faber

Editor chefe

faber@dentalpress.com.br 